\title{
近接掘削工事に起因する戸建住宅の基礎の障害について STRUCTURAL DAMAGE OF DETACHED HOUSES' FOUNDATION CAUSED BY NEIGHBORING EXCAVATION WORKS
}

\author{
田村昌仁*, 伊奈 潔**, 藤井 衛***
}

Masahito TAMURA, Kiyoshi INA and Mamoru FUJII

\begin{abstract}
This purpose of this study is to present the characteristics of damage of detached houses caused by the neighboring excavation work. Using the field data, we investigated the relationship among the level of damage, the ground deformation and the degree of structural damage in detached houses. Damage was larger in the case when the detached house had the cracks in the continuous footing before excavation. It was also noted that damage increased when the inclination angle of houses to the horizontal was larger than $5 / 1000$, irrespective of whether the continuous footing had reinforced or not.
\end{abstract}

\section{Keyword : footing, settlement, detached house, excavation} 基礎, 沈下, 戸建住宅, 掘削

\section{1.はじめに}

住宅に不同沈下が発生した場合, その発生原因には $2 つ の$ 要因が 考えられる.一つは内的要因と呼ばれるもので, 基礎の選定ミスや 不十分な地盤調查法, 地業の転圧不足など, 主として設計者や施工 者の注意義務の䍐慢に基づくものである.他の 1 つは外的要因と呼 ばれるもので，シールド工事や下水道工事など主に地盤の変動によ って周辺の住宅に不同沈下を発生させるものであり，一概に設計者 や施工者の㸡疪とは断定できないものである.内的要因については, 先般, 建築基準法の改正に伴い, 国土交通省告示 1347 号が制定さ れ，戸建住宅の基礎の寸法・配筋等の最低基準が規定されたり，ま た，最近は圧密沈下に基づく不同沈下の実態調查も盛んに研究され てきており，この方面の研究資料も充実しつつある 1) 6)．一方， 外的要因については，掘削工事に伴う山留壁の変位や山留壁周辺の 地盤面の変位について調查・報告がなされた論文や 7) 9)，沈下障 害の調査方法や評価方法に関する文献はあるものの 10) 12)，不同沈 下の大きさと住宅の障害を調查した最近の研究は少なく, わずかに 沈下障害の現状を報告した研究がいくつかあるにすぎない 13),14) .

本報告では，近接掘削工事を行う際に周辺住宅に発生する沈下障 害を極力防止できるよう掘削工事の施工者に有効な情報を提供す る事を目的に，これまで近接掘削工事によって発生した住宅の沈下
障害を分析し，地盤変動の大きさと住宅の沈下障害レベルとの関係 や障害が発生しやすい建物及び基䃈の鉄筋の有無が住宅の不同沈 下量に及ぼす影響を明らかにした。

\section{2. 近接掘削工事周辺住宅の基礎の仕様について}

2-1. 調查方法

調査対象とした地域は，都内及び近郊の 42 地域で図-1に示すよ 亏な軟弱な地盤（粘性土 $\mathrm{N}$ 值 5 以下，砂質土 10 以下）である，表 -1 には, 調査方法, 調査項目を示しており, 建勧年代や基磷仕様, 障害度・近接掘削工事の概要など多岐に及んでいる.調査棟数は合 計 1858 棟であるが，調查項目の全てを調査棟数のすべてに対して 把握できたわけではないので, 分析結果の図表毎に棟数を示してい るが，ほとんどの分析は 200 棟以上の結果に基づいている.

\section{表-1 沈下障害の調查項目}

\begin{tabular}{|c|c|}
\hline 規模構造 & 構造 - 階数 - 建築面積 - 延床面積 - 平面形状 \\
\hline 建物仕様 & 屋根・外壁・建筑年代・基碄形式 \\
\hline 基礎仕様 & 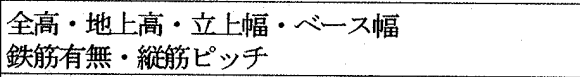 \\
\hline 障害調查 & 不同沈下量・傾斜量・変形量・障害度 \\
\hline その他 & 盛土・増改筑有無 \\
\hline 近接工事概要 & 土質区分・掘削幅 ·掘削媣 · 矢板種類・矢板長等 \\
\hline
\end{tabular}

* 独立行政法人建築研究所 工博

** 中央建鉄中央技術研究所

*** 東海大学工学部建築学科 教授. 工博
Building Research Institute, Ministry of Construction, Dr. Eng.

Chuo Kentetsu Chuo Technical Research

Prof., Dept. of Architecture and Building Engineering, Faculty of Engineering, Tokai Univ., Dr. Eng. 


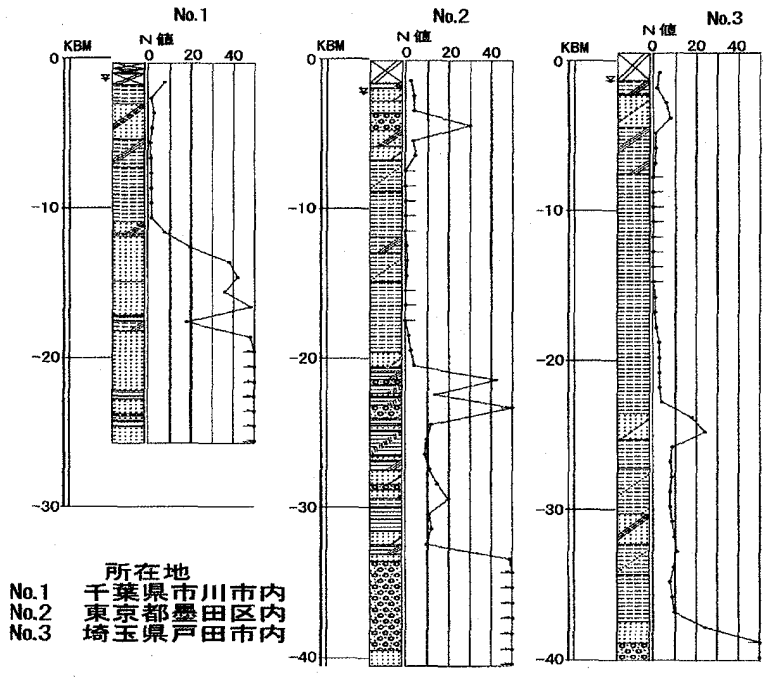

図-1＼cjkstart調查地域の代表的な地盤条件

基礎仕様の形状測定は，地上部は直接実測し，埋設部は鉄筋を挿 入してベース位圆, ベース幅の測定を行った．基礎鉄筋の有無に関 してはメタル探知機及び聞き取りに基づいて判定した，その他の項 目については聞き取り，若しくは目視調査を行った。

\section{2-2. 基礎仕様調查結果}

基礎仕様の調査結果から判断すると，標準的な仕様は図-2のよう であった，なお，この図は，基礎寸法，鉄筋の有無を確認した 243 棟を対象にしている．鉄筋コンクリート基礎（以下「有筋基礎」） の基礎高は 35〜60 cm，50 cm 以上の高さのものが多く, 80〜 $100 \mathrm{~cm}$ のものも見られた．立上がり厚は $13 \sim 15 \mathrm{~cm}$ と，やや無筋 コンクリート基礎（以下「無筇基礎」）（12〜13 cm）に比べて厚く, ベース幅は 35〜55 cm と無筋基礎との差は見られなかったが, 無筋 基礎の中にはベースのないものも多く見られた。鉄筋径は調査でき なかったものの, 縌筋のピッチは@300 で有笳基礎は全体の 3 割強 であった。

我が国の住宅基礎の仕様に関しては，従前の建築基淮法では特別 の規定がなかったため，住宅金融公庫の工事標準仕様書が参考とさ れてきた感があるが, 有筋基礎の仕様が追加されたのは, 1982 年 の改定である 15)。図-3 は鉄筋の有無と建築年代を確認した 285 棟 を対象に整理し，建築年代に対する基礎の鉄筋の有無と割合を示し たものである．この図から 1982 年の仕様改定後から有筋基䊙の割 合が多くなっていることがわかる.

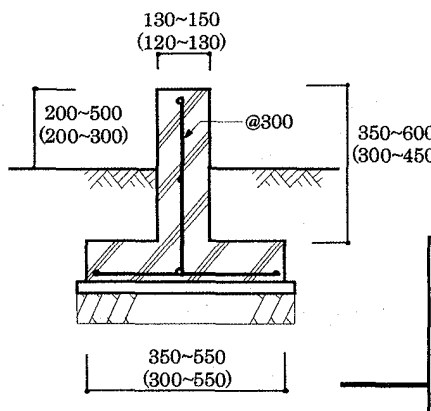

（）内は無筋基碳寸法を示す

図-2 実態調查による基礎形状

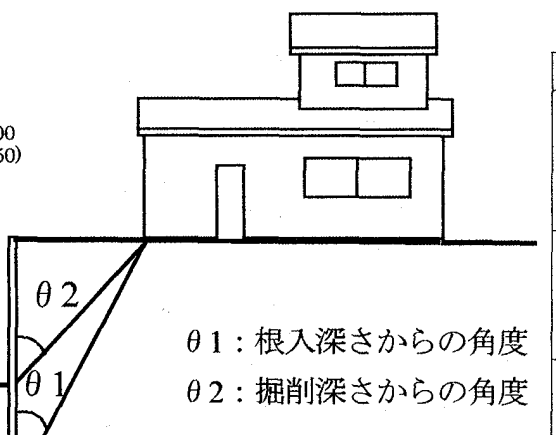

図-4 角度の取り方

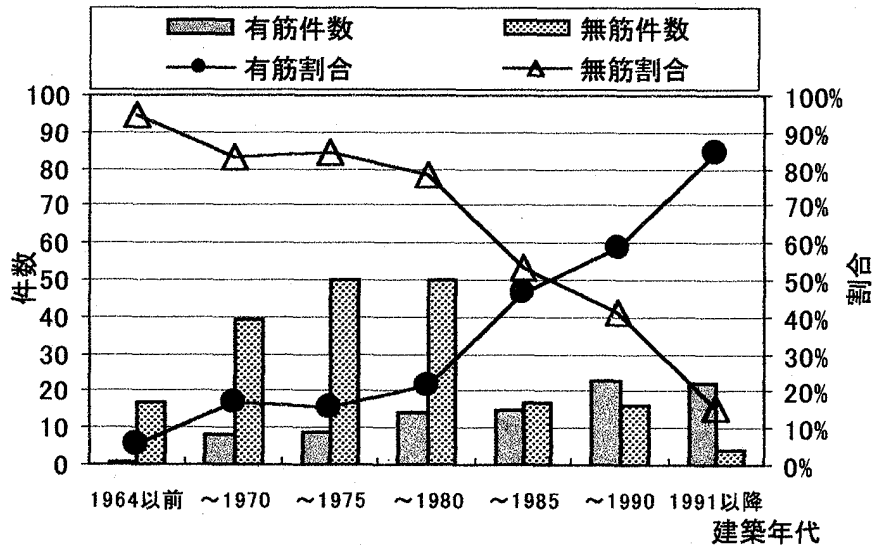

図-3 建築年代と基礎鉄筋の有無(285棟)

\section{3. 近接掘削工事と障害度}

3*1. 近接掘削工事によって発生した地盤変動の大きさと障害発生 との関係

近接掘削工事によって障害が発生した住宅のうち，掘削幅、掘削 梁さ、矢板長等の工事規模が判明している 223 棟について基礎の鉄 觔有無別に障害の発生状況を分析した結果を以下に示す.

対象とした工事は掘削深さが $4 \mathrm{~m}$ 程度の小規模の開削工事である. 仮設山留は地盤条件などにより異なるが，主に軽量銅矢板及び鋼矢 板，1２段程度の木製又は鋼製支保工である，図-4 は建物の位置 と掘削深さや矢板長の先端とのなす角（以後「近接角」と呼ぶ）と の関係を示したものである. 矢板長に対しては $\theta_{1}$, 掘削深さに対し ては $\theta_{2}$ として表している. $\theta_{1}$ ，と $\theta_{2}$ を障害のパラメータとしたの は次の理由による．掘削時においては，山留壁の変形や掘削底の膨 れ上がり等が周辺地盤を変動させる可能性があり，この場合は $\theta_{2}$ の大きさが問題となる.一方，埋戻し時においては，矢板の引抜き が周辺地盤を変動させる可能性がある.17)この場合 $\theta_{1}$ の大きさが 問題となる，以上の理由により，掘削深さと矢板全長の 2 つの場合 の近接角を検討の対象とした，なお，障害度は障害内容別に表-2の ように区分した。ここで言う障害の発生とは表-2 の内容（区分 A.B.C) のことを指す，図-5 は近接角の大きさと障害の発生件数を 鉄筋の有無別に示したものである．図-5によると，障害の発生は基 礎の鉄筋有無に関わらず近接掘削工事に対して建物の位置が，矢板 長に対する近接角 $\theta_{1}$ で $30^{\circ}$ の範围，掘削深さに対する近接角 $\theta_{2}$ では $45^{\circ}$ の範囲までの位㯰にある場合に障害の発生頻度が大きい ことがわかる．なお，この図は，障害の発生を確認したもののうち 矢板長, 掘削深さと住宅までの距離の関係を把握した 223 棟の分析

\section{表-2 障害度区分}

\begin{tabular}{|c|c|c|}
\hline \multicolumn{2}{|c|}{ 区分 } & 障害の内容 \\
\hline \multirow{4}{*}{ A } & $\mathrm{A}-4$ & \multirow{4}{*}{ 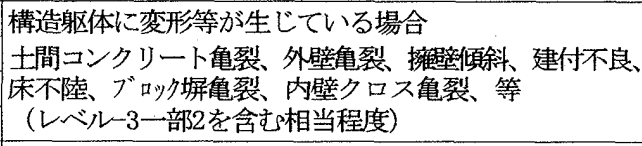 } \\
\hline & $\mathrm{A}-3$ & \\
\hline & $A-2$ & \\
\hline & $A-1$ & \\
\hline \multicolumn{2}{|r|}{ B } & 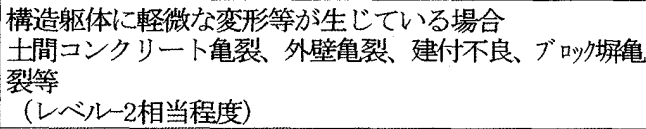 \\
\hline & C & $\begin{array}{l}\text { 構造躯体には変形等が生じていない場合 } \\
\text { 土間コンクリート刍裂、建付不良等 } \\
\text { (レベルー1相当程度) }\end{array}$ \\
\hline
\end{tabular}
•障害度Aはさらに1〜4に障害度を区分、詳細は表3を参照 
結果である， $\theta_{2}$ に関しては，これまで $\theta_{2}<45^{\circ}$ の範囲が影響範囲 であると考它れていたが，今回の調査地域のような軟弱地盤の場 合では, $\theta_{2}=45^{\circ} \sim 60^{\circ}$ であってもある程度の障害が発生してい た. すなわち， $\theta_{2}>45^{\circ}$ でも障害の発生が皆無とはいえないよう である.

図-6 は, 建物端の沈下量と住宅までの距離を矢板長で除して無次 元化して表した数値との関係を示したものである.これによると， 影響範囲は矢板長の最大 2.5 倍程度であることがわかる.ここで言 う沈下量は内部床における水盛管測定から図-7 の方法により表し た值であり， $\mathrm{C}$ 点の不同沈下量 $\alpha$ である，本来，沈下量>不同沈下 量であるが，住宅の奥行きは概ね $10 \mathrm{~m}$ 程度で, 対象とした工事は 掘削深さが $4 \mathrm{~m}$ 程度の小規模であるから, 基準点となる $\mathrm{A}$ 点の沈下 は微小であり，沈下量○不同沈下量と見なし，ここでは便宜上，不 同沈下量を沈下量として扱った．また，住宅敷地の地盤条件や住宅 の構造等，住宅側の要因により近接掘削工事反対方向に不同沈下す るケースも見られたが，ここでは掘削工事側の要因を明確にするた

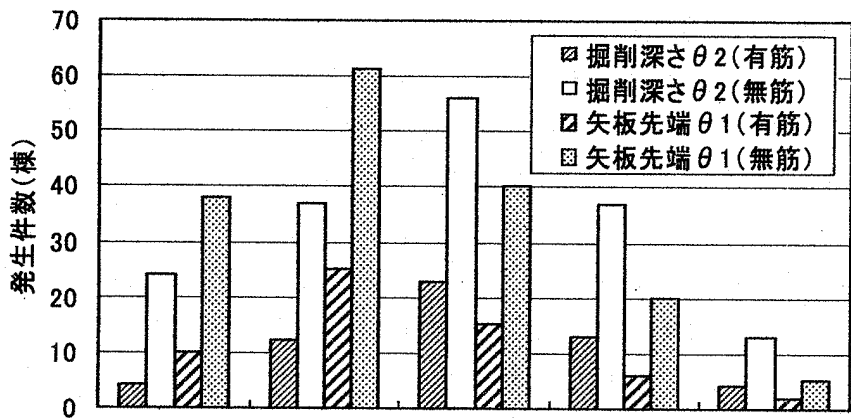

15> $\theta \quad 15 \leqq \theta<30 \quad 30 \leqq \theta<45 \quad 45 \leqq \theta<60 \quad \theta \geqq 60$ 図-5 近接角の大きさ $\theta\left({ }^{\circ}\right)$ と障害発生件数（223 棟)

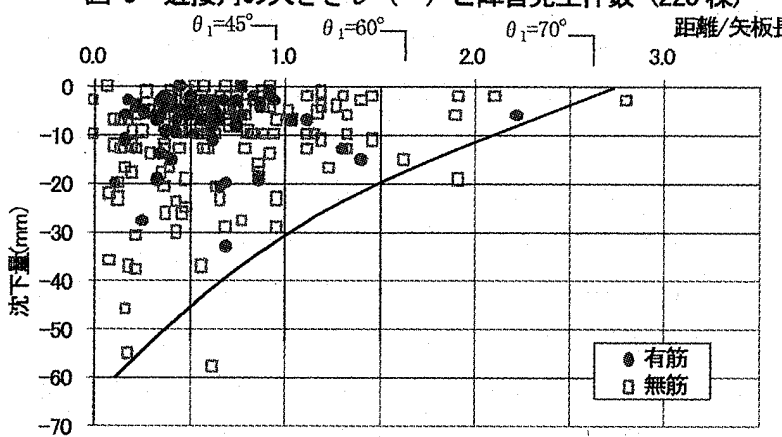

図-6 距離/矢板長と沈下量の関係 (205 棟)

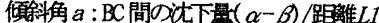
便斜角 $b: \mathrm{AB}$ 問O沈下量 $(\beta) /$ 跬雕 $L 2$ 変形角 $\theta$ : 傾科角 $a$ 一傾斜角 $b$

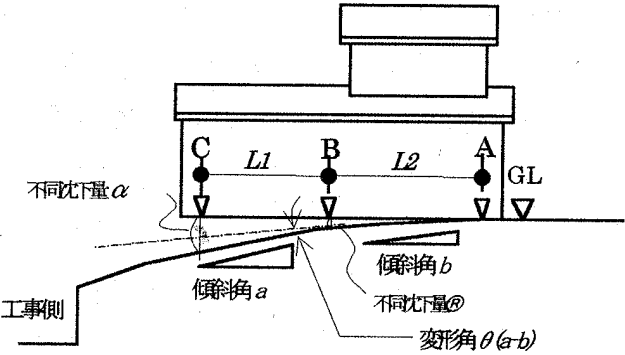

図7 傾斜角と变形角の算出方法

め, これらのデータは除外した。 なお，図-6 は矢板長と近接建物ま での距離，及び不同沈下量を確認した 205 棟の分析結果である.

3-2. 工事の規模と障害度との関係

図-8,図-9 は同様に工事規模と障害度の関倸を, 基礎の鉄笳有無別 に整理したものである，前章の障害の発生頻度では，基礎の鉄筋有 無に関わらず，矢板長に対する $\theta_{1} \leqq 30^{\circ}$ ，掘削媣さに対する $\theta_{2} \leqq$ $45^{\circ}$ の範囲が最も大きくなったが，障害度を見ると，無筋基礎では $\theta_{2} \leqq 15^{\circ}$ が最も障害程度が大きい，また， $15^{\circ}<\theta_{2}<45^{\circ}$ までは 障害度は小さくなるものの， $\theta_{2}>45^{\circ}$ を越えると再び障害度が大 きくなる傾向が見られる.しかし，有筋基礎では角度が大きくなれ ば障害度は小さくなる傾向が認められ，無箭の場合とは異なる傾向 が見られる。

無笳基礎の場合，近接掘削工事により住宅全体が大きく沈下する と障害度は当然大きくなるが， $\theta 2 \geqq 45^{\circ}$ とかなり離れている場合 でも，建物の片側だけが沈下すると，沈下量が少なくても障害度が大 きいようである，一方，有筋基礎の場合，非常に近接して掘削工事 が施工され，住宅全体に沈下が生ずるような場合でも A ランクの損 傷が生じる割合が少なく，無䇗基礎に比べて障害度が小さいことが わかる，なお，図-8，図-9 は，それぞれ掘削深さと近接建物までの 距離, 障害度を確認した 223 棟及び矢板長と近接建物までの距離, 障害度を確認した 220 棟を対象としている．また，有能基礎怔無䇗 基礎に比較して，障害度がかなり低いが，かなり近接していると有 筋であっても著しい障害が認められる割合が 1 割程度あるので，地 盤の不同沈下に対しては現状の有筋仕様は必ずしも十分でないと 考えられる.

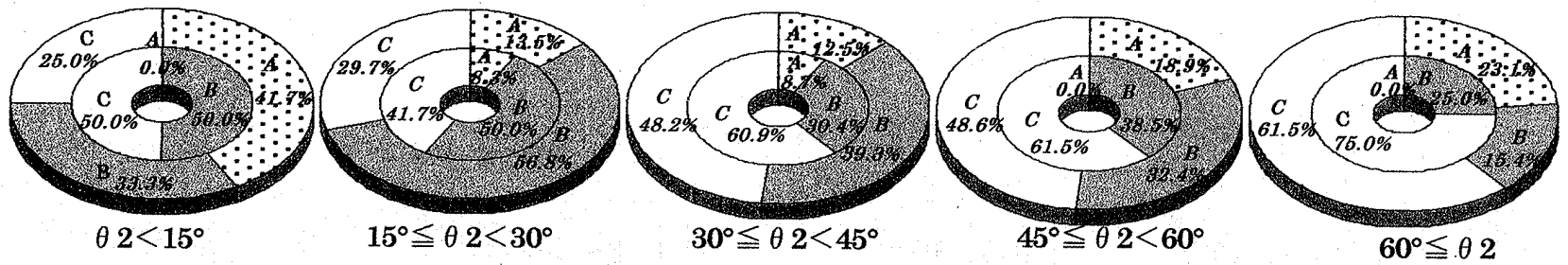

図-8 掘削深さの角度之障害度の割合（外側：無笳基礎 167 棟 内側 : 有筋基礎 56 棟 計 223 棟）

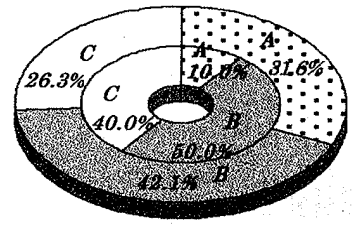

$\theta 1<15^{\circ}$

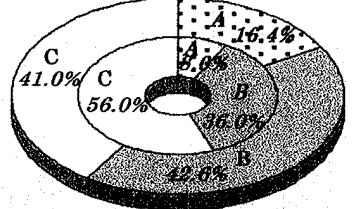

$15^{\circ} \leqq \theta 1<30^{\circ}$

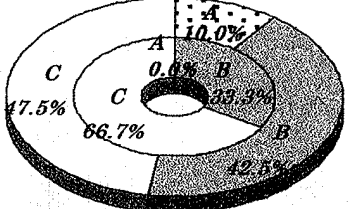

$30^{\circ} \leqq \theta 1<45^{\circ}$

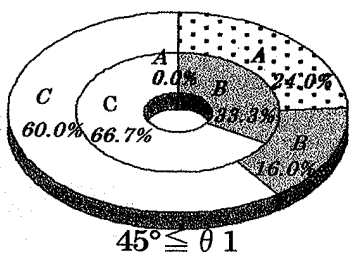

$45^{\circ} \leqq \theta 1$

図-9 矢板先端からの角度と障害度の割合（外側 : 無筋基礎 164 棟 内側 : 有筋基礎 56 棟 計 220 棟） 
図-10 および図-11 は, 近接掘削工事側への住宅の不同沈下量と障 害度の関係を示したものである. 障害度は, 定量的な目安を得るた め, 表- 2 及び後述の表-3に基づいて, 障害度が大きいグループと比 較的軽微なグループに区別した．障害が小さいものには，不同沈下

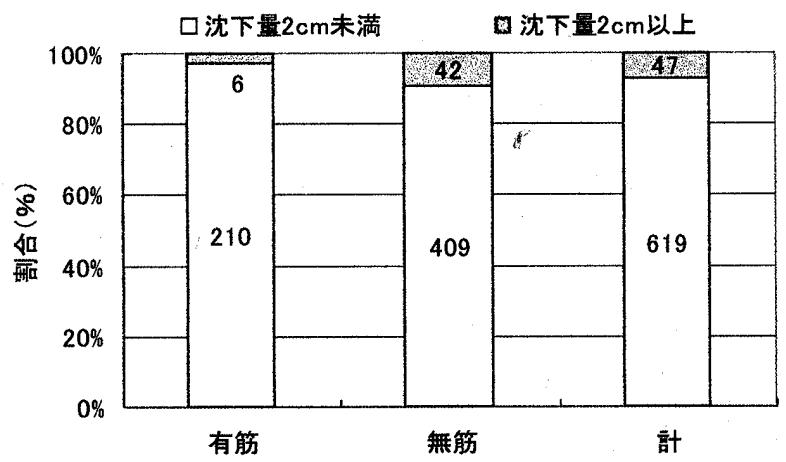

図-10 不同沈下量と障害の関係（グラフ内の数字は件数 計 666 棟） 損俉度の小さいA-1、B、Cの場合

口 沈下量 $2 \mathrm{~cm}$ 未満

圆沈下量 $2 \mathrm{~cm}$ 以上

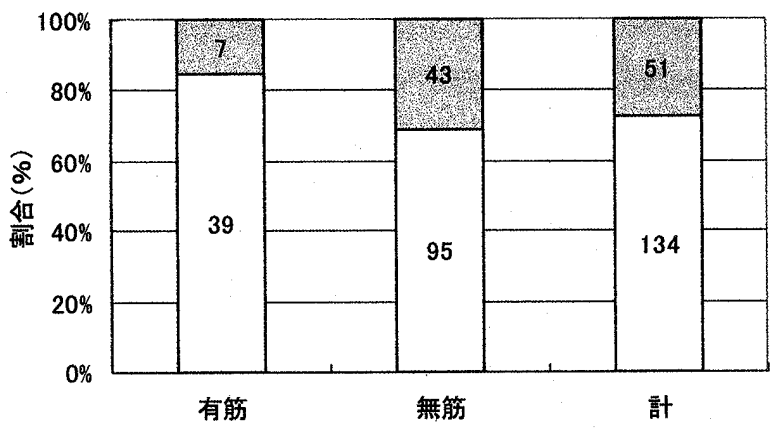

図-11 不同沈下量と障害の関係（グラフ内の数字は件数 計 368 棟） 損傷度の大きいA-4、A-3、A-2 の場合

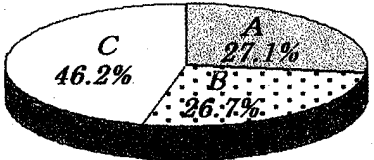

基脴に刍裂無し

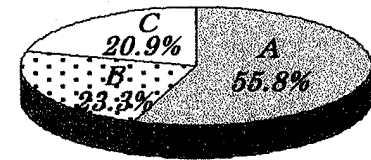

基礎に亀裂有り

图-12 従前の基礎亀裂の有無と障害度の割合（253 棟）

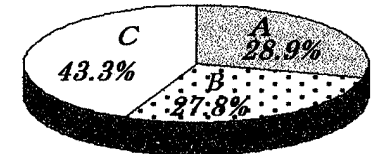

開口部無し

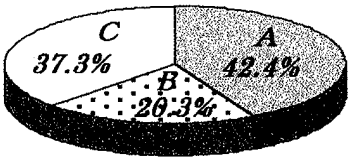

開口が大きいもの

図-13 開口部の大小と障害度の割合（253 棟）

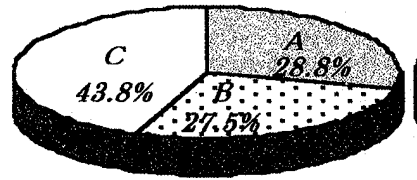

$3 / 1000 \geqq \theta$

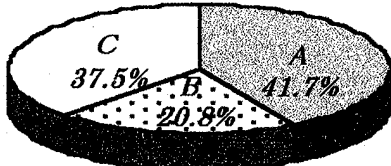

$3 / 1000<\theta<5 / 1000$
量が $2 \mathrm{~cm}$ を越えるケースは少ないが，障害が大きいと $2 \mathrm{~cm}$ を越え る不同沈下が生じる割合がかなり大きくなっていることがわかる. 日本建築学会建築基礎構造設計指針では，木造建物布基礎の沈下量 の限界值を標準值 $1.5 \mathrm{~cm}$ ，最大值 $2.5 \mathrm{~cm}$ としており 18 )，この数值は 妥当なものと判断される.

3-3. 地盤変動による障害が発生しやすい建物

障害度は掘削深さ等の工事側の条件により大きく影響を受ける ことは明確であるが，近接掘削工事により障害が発生した住宅を分 析してみると，工事着工前からすでに亀裂が生じている「従前の基 礎の亀裂」(図-12）や開口部が大きい建物（図-13）ほど障害度が大 きくなり，住宅側の条件によっても障害度に及ぼす影響が強いこと がわかる．逆に，一見して障害度に強く関与していると思われるよ うな、工事着工前からすでに生じている建物の傾斜具合「従前の傾 斜量」（図-14）は，障害度に大きく影響を及ぼす要因ではないこと がわかる、一方，建築年数（図-15）に関しては，逆に築年数が多く なれば障害度が小さくなるような傾向が見られる.なお，図-12〜図 -14 は，障害度と従前の損傷，開口部の大きさ，傾斜角を把握した 253 棟を対象とし, 図-15 はそううち建築年数を確認した 252 棟を対 象としている。

3-4. 掘削樑さが 2 4m の工事における住宅の被害要因 対象となった工事の掘削深さは 1 $8 \mathrm{~m}$ であるが, 工事側の要因を 一様にするため, 頻度の高い $2 \sim 4 \mathrm{~m}$ の工事について被害要因の検討 を試みた。図-16 は，地盤条件と沈下量，掘削深さを把握した 142 棟に対して，地盤種別毎に掘削位置から住宅までの水平距離と沈下 量をまとめたものである，図-3に示すとおり，これらの地域は沖積 層が $10 \sim 30 \mathrm{~m}$ 堆櫝する軟弱な地盤地域であるが，粘性土地盤は砂 質土地盤に比べてさらに沈下量が大きく遠方まで影響が及ぶ傾向 が見られる. 図-17，鉄筋の有無別に同様にまとめたものであり，図 -18 は 7 段階に区分した沈下量の大きさと件数を鉄筋の有無別に整 理したものである. 図-17 より，無筋基礎は有筋基礎に比べて沈下 量も大きく掘削箇所から $6 \mathrm{~m}$ 付近まで不同沈下が生じる.また，図 -18 より有箭基礎の場合，沈下量が $3 \mathrm{~cm}$ 以下がほとんどであるのに 比べて, 無筋基礎ではこれを超えるものも多い, なお, 図-17 は鉄 筋の有無と沈下量, 掘削箇所からの距離を把握した 87 棟を対象と し,図-18は鉄筋の有無と沈下量を確認した 89 棟を対象にしている。

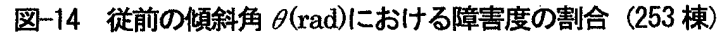

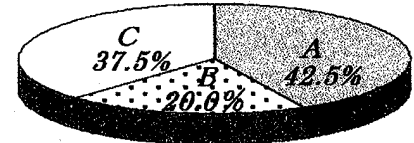

建築年度 10 年末満

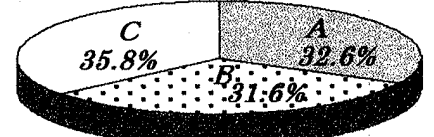

筑 10 年以上 20 年末満

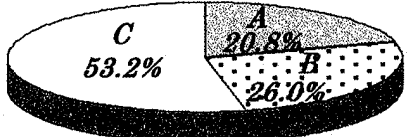

築 20 年以上

图-15 建築年数と障害度の割合（252 棟） 


\section{4. 基礎の鉄筋有無と障害度の関係}

4-1. 基礎の鉄筋の有無が不同沈下量や変形角に及ぼす影響

図-19, 図-20 は，基礎の鉄筋の有無と沈下量（不同沈下量），傾 斜角を把握した 117 棟に対して，上部構造に見られる傾斜量，変形

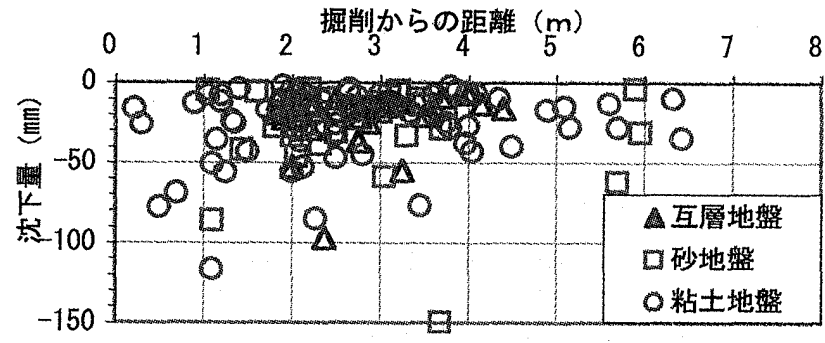

図-16＼cjkstart地盤種別の沈下量 (142棟)

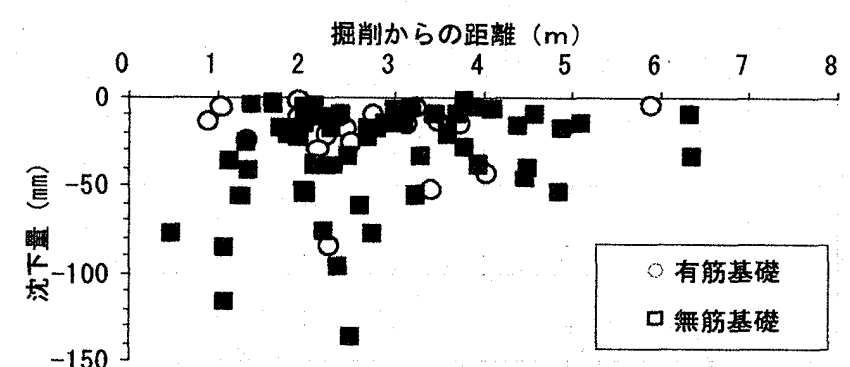

図-17、基礎の鉄筋有無別の沈下量（87棟）
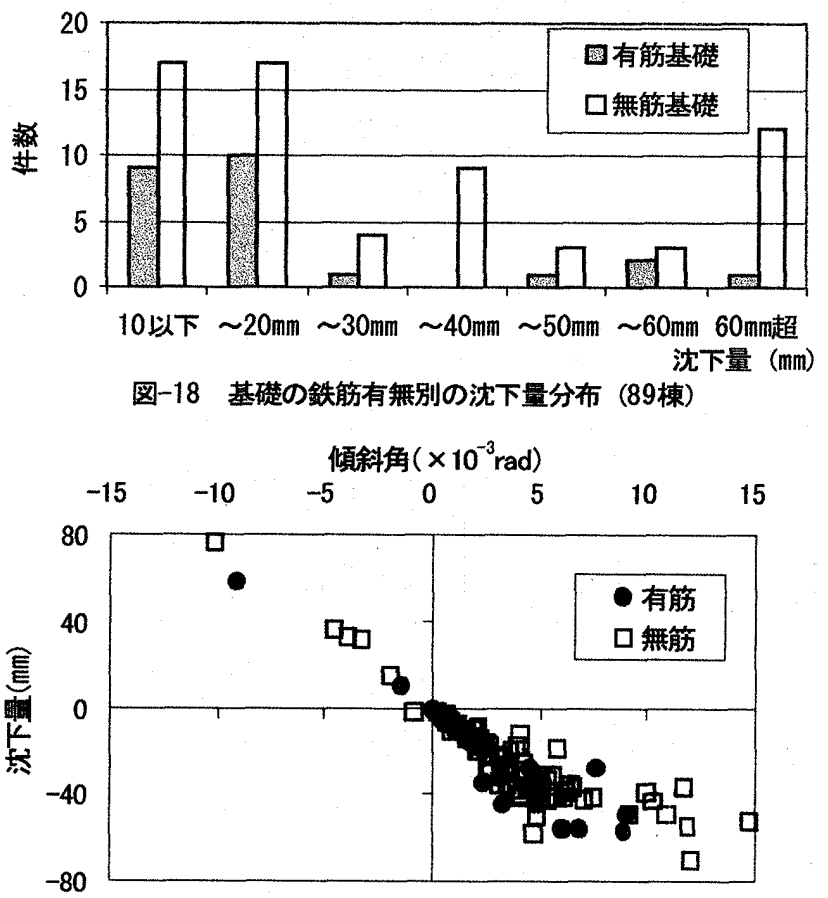

図-19＼cjkstart基礎の鉄筋有無と傾斜角（117 棟）
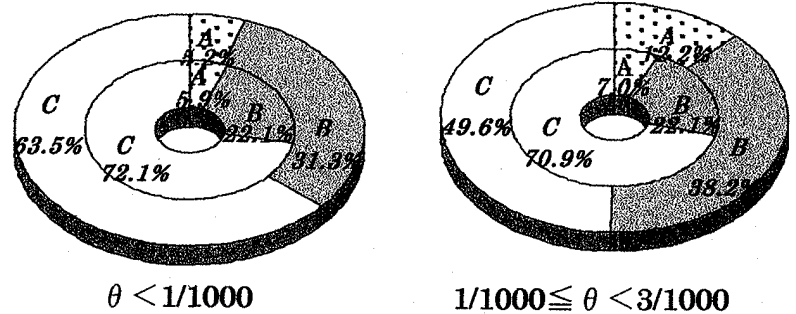

$1 / 1000 \leqq \theta<3 / 1000$
量との関係を鉄筋の有無別に整理したものである．各值は水盛管に よる床面の工事後の測定結果をもとに，先の図-6に示す方法によっ て算出した。 傾斜角は工事箇所側の傾斜角 $\mathrm{a}$ として求めている. 水 盛管の測定位置は，4 隅とその中間点であり，図-6の L1 と L2 は 工事䉪所にほぼ值交する面の奥行きを二分するように設定している. 不同沈下量や傾斜角が負の値となるのは, 住宅敷地の地盤条件や住宅 の構造等, 住宅側の要因により近接掘削工事反対方向に不同沈下し ているケースである．また，変形角が負の値となるのは建物が「中く ぼれ型」に変形する場合である，但し，障害度との関係を示す図-21， 図-22に関しては角度の正負を区別せず絶対値しした。

図-19 と図-20より明らかなように, 無筋基礎では不同沈下が生じ た場合，沈下量が大きく生じそれに伴い傾斜角，変形角も増大する 傾向を示している，これに対して有䈘基礎の沈下量は無筋基礎に比 べて小さく, 変形角は不同沈下量が増大しても大きく生じないこと がわかる.このことから有筋基礎は，沈下傾斜と変形に対して抑止 効果があることがわかる.

\section{4-2. 変形角と障害度の関係}

基礎の鉄筋有無別の変形角々障害度の関係を図-21 に示す。こ の図は，障害度と鉄筋の有無，変形角を把握した 621 棟を対象に分 析している．障害度は基礎の変形量と相関すると考えられるが，同 図によると 5/1000 以上の変形が生じた場合は基礎の鉄筋有無に関 わらず障害度が大きくなるが，それ以下では同量の変形が生じても， 有筋基礎の方が障害度が小さくなることがわかる.

図-22 は，図-21 の建物のうち，近接掘削工事箅所代直交する一辺の基礎 の亀裂幅と本数 (損稘程度) の関係を把握した 182 棟に対して, 変形角との 関係を整理したものである．無筋基礎は沈下が生ずると即座に大きな亀裂 が発生するのに対して，有笳基整は5/1000 までさ亀裂幅が小さく，変形量 の增大に伴、数力所に分散して損傷寸る傾向が見られる．5/1000 を超える と急激に龟裂幅が大きくなり無筋基礎と大差が無くなる．これは変形量 5/1000末満について言えば, 図-23のように建物端部が沈下し中央が折れる
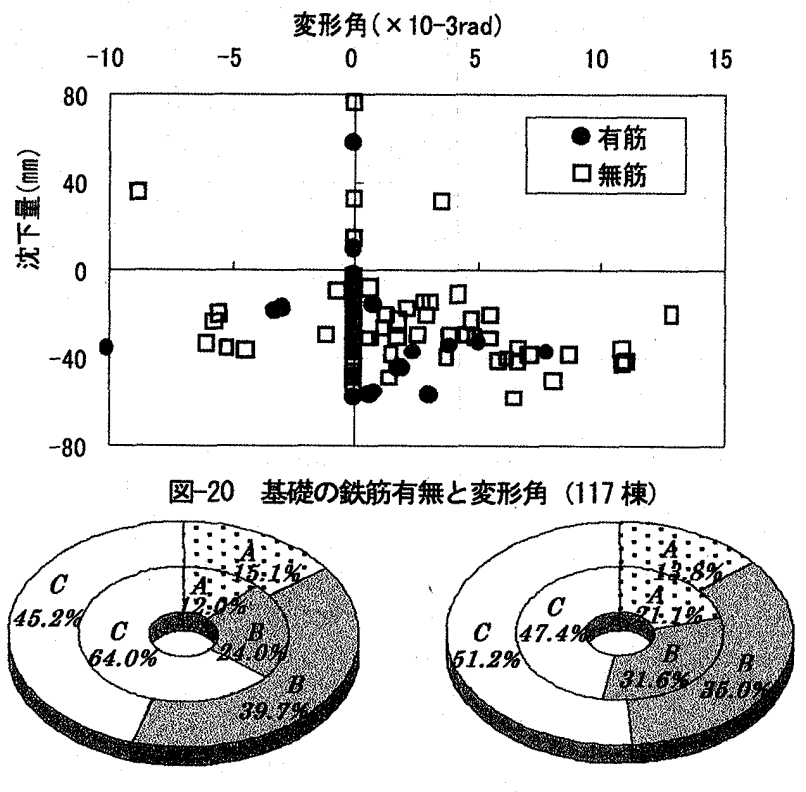

$3 / 1000 \leqq \theta<5 / 1000$

$5 / 1000 \leqq \theta$

図-21 変形角 ( $\theta$ : rad ) と障害度の割合 (外側 : 無笳基礎 423 棟 内側 : 有筋基礎 198 棟 計 621 棟) 
ような変形を生じた場合, 無筋基礎では変形力゙集中するのに対して, 有筋基 整では基礎佣性が大きいため基礎全体が一体に弓なりとなり，応力が分散さ れるため障害度が緩和されるものと考えられる. 地盤変動が生じた場合, 変 形を生じさせないために有䇗として基礎の㴊性を高めることは非常に重要 であるが, 桨形が生じた場合でも基礎の勒性により障害度か軽減できること がわかる.

図-24 は, 障害度の最も大きいランク A のうち, 基礎の鉄筋有無 や障害度（表-3の 4 段階）を把握し，さらに『公共事業に係る工事 の施工に起因する地盤変動により生じた建物等の損害等に係る事 務処理要領』12)並びに『損失補償標準算定書』16)に淮执して補償額(修 復金額)が試算できた 81 棟を対象に, 基礎の鉄筋有無別に障害度を 示したものである.

無筋基礎であると障害度 A-4 の割合が多くなり，修復金額が非常 に高額になる.これは障害度 A-4 になると, 通常の損傷部分の修復 に加えて沈下傾斜が著しく, 揚屋（沈下修正）を行い修復する必要 が生ずるからである. 沈下修正が必要かどうかの判断基準は,事業損 失補償の事務処理要領等では明確化されていないが，傾斜角で $5 / 1000$ 以上を目安に, 障害状況によって判断されているようである. 図-25 は，障害度の検討において沈下修正（揚屋）が必要とされた 建物のうち, 傾斜角と変形角が把握できた 125 棟を対象に, 傾斜角 と変形角の関係を整理したものである.傾斜角が $7 / 1000$ 以上では, 変形の有無に関わらず「建物が傾いていることを意識する.」「床に 置いたものが転がる」「排水不良や建具が流れる」など, 変形によ

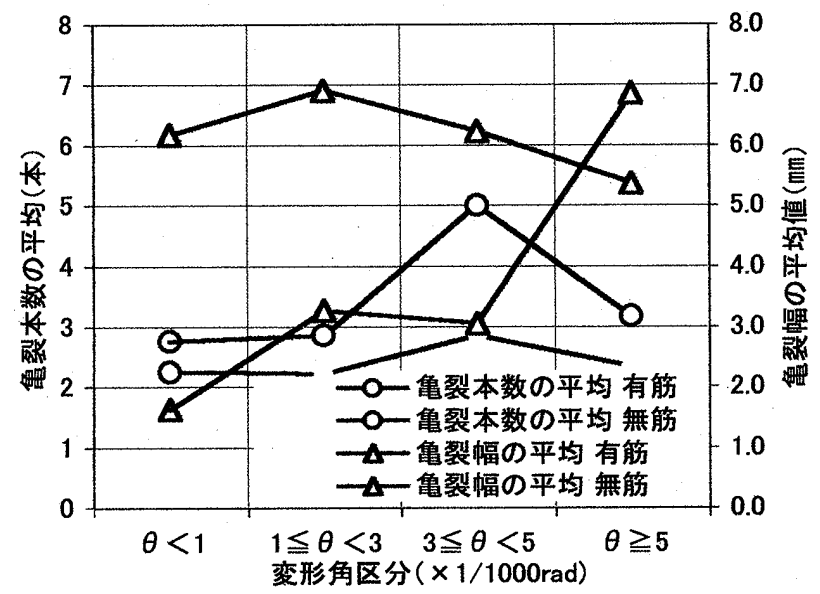

図 -22 変形角と基礎の損傷程度の関係 (182棟)
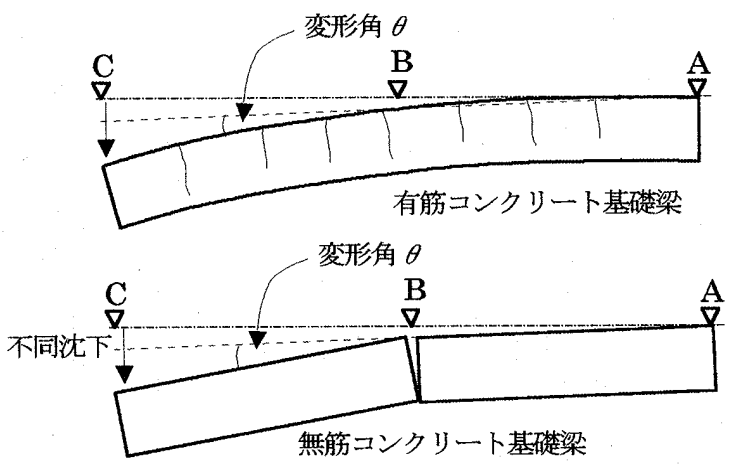

図-23 不同沈下による基礎の変形パターン
る損傷よりも建物が全体的に傾斜することによる機能面の障害や 居住性が損なわれることから沈下修正が必要と判断されている。 ま た, 傾斜角が $5 / 1000$ 以下の場合で沈下修正が必要とされた建物で は, 2/1000 以上の変形角が生じ, 傾斜は大きくないが変形による損 傷が著しく沈下修正が必要と判断されているものと考えられる.

表-3 障害度Aの詳細区分

\begin{tabular}{|c|c|c|}
\hline \\
\hline 障害度区分 & 修復金額 & 障害内容 \\
\hline$A-1$ & 200万末満 & 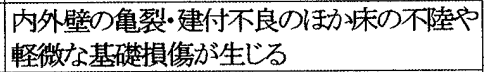 \\
\hline A-2 & 200～300万末満 & A-1に加えて目立つ基礎損傷が見られる \\
\hline$A-3$ & 300～500万未満 & $\begin{array}{l}\text { 構造部の損傷が大きく一部沈下修正が必要 } \\
\text { となる場合がある }\end{array}$ \\
\hline$A-4$ & 500 万以上 & $\begin{array}{l}\text { 構造部の損傷や傾斜が著しく沈下修正が必 } \\
\text { 要となる }\end{array}$ \\
\hline
\end{tabular}

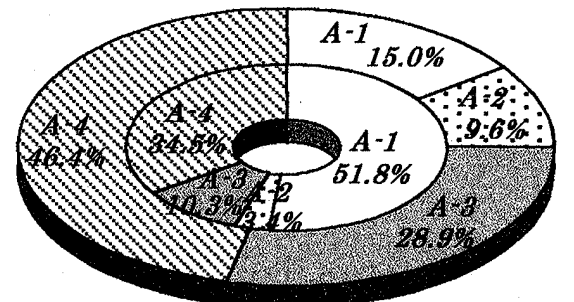

図-24 基礎の鉄筋有無別の障害度 $A$ の詳細区分 (外側: 無筋 52 棟 内側: 有筋 29 棟 計 81 棟)

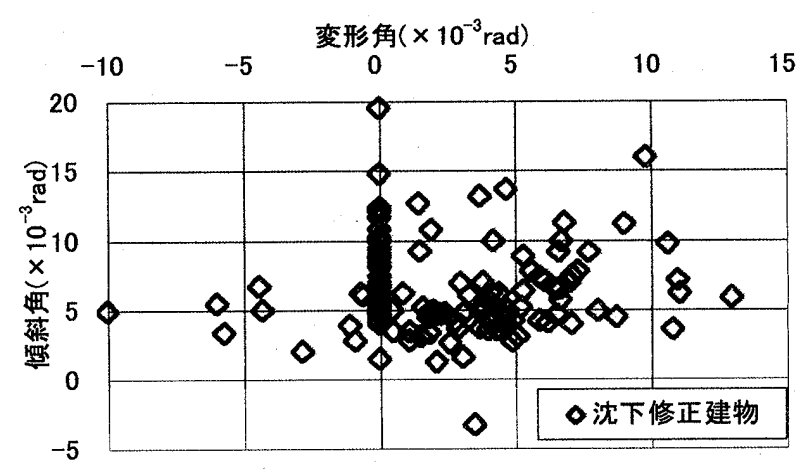

図-25 沈下修正建物の変形角之傾斜角 (125棟) 


\section{5.まとめ}

大規模な地下工事を行う場合には，周辺地盤の変動に十分注意し て設計施工が行われるが，掘削深度 5 6m 未満の比較的小規模な 掘削工事では沈下挙動を正確に予測することはまれである。そのた め，予期しない理由により地盤変動が生じ，不同沈下障害が発生す ることがある，その原因としては，地盤に起因するものばかりでな く，建物側に問題がある場合もある．特に有筋の布基礎が増え始め たのは 1982 年以降であり，現存する住宅には無筋基䃈のものもま だ数多く存在している.このことを踏まえて，以下に示す本研究の 内容に配虑して適切な掘削工事を行えば，近接掘削工事による周辺 住宅の不同沈下障害をかなり減らせることができると考えられる。 以下に本論文の主な結論を䈏条書きに示す。

1）軟弱地盤において，矢板先端からの近接角が $30^{\circ}$ 以下，掘 削深さに対する近接角が $45^{\circ}$ 以下の掘削工事においては， 障害の発生が顕著である.

2），不同沈下が発生する範囲（矢板から建物最短部までの距離） は矢板長の 2.5 倍程度である。

3）無筋基礎は掘削梁さに対する角度と障害度との間に明確な 関係が認められるが，有筋基礎では密接な関係が認められ ない.

4）有筋基礎は無筋基礎に比較して障害度は低いが，矢板に近 接していると無筋と同様に著しい障害が発生する。

5）不同沈下量が $2 \mathrm{~cm}$ 超えると，重度の障害を有する建物が 急增する。

6）工事着工前から亀裂が生じている建物や開口部の大きい建 物ほど障害が発生しやすい,

7）無筋基礎では不同沈下の発生により, 傾斜角, 変形角も増 加するが, 有筋基礎では変形角の増大はあまり見られない，

8）変形角が $5 / 1000$ 以上になると, 基礎コンクリートの鉄筋の 有無に関わらず建物には大きな障害が発生する。

9）沈下修正が必要かどうかの判断基準の目安は，傾斜角の場 合 5/1000の大きさであり，変形角の場合 $2 / 1000$ の大きさ である。
参考文献

1. 芳賀保夫:木造建築物の不同沈下障害 (その 1 : 傾斜角と損賃の発生)， 日本建築学会大会学術講演梗概集, pp1165-1166, 1987.10

2. 芳賀保夫:木造建物の不同沈下と障害, 土と基䃈 Vol.41No.11, pp59-64, 1993. 11

3. 小規模建築物基碳設計の手引き，日本建築学会，1992.5.

4. 田村昌仁: 軟弱地盤に扔ける住宅の不同沈下, 日本建築学会構造系論 文報告集№.420, pp 153-161，1991. 12

5. 藤井衛 - 田村昌仁 - 後藤年芳 - 伊集院博 : 諏訪湖周辺の低層住宅の不 同沈下調查事例による基磷の沈下抑制効果について，日本建築学会構 造系論文報告集NNo.538，pp93-100，2000.12

6. 藤井衛・伊集院博 - 田村昌仁・伊奈潔 : 兵庫県南部地震にお打る戸建 て住宅の液状化被害と修復, pp9-14，土と基磷 Vol.46NNo.7，1998.7

7. 間片博文・山田孝治・高橋良文・吉田保 : シールド掘削に执ける地 盤沈下と家屋被害について，土と基礎 Vol.28.No.6，pp.59-66，1980.6

8. 杉本隆男・佐々木俊平 : 山留め-掘削工事に伴う周辺地盤の変形の要 因分析，土質工学会研究発表会，p152-p 153，1985.6

9. 和田克哉：トンネル標準示方甾 (開削工法編) の地盤変状予測基碟工, Vol25, No.4, p17-p 22, 1997

10. 東京都下水道局，損害補償実務の手引き， 2000

11. 横浜市下水道局，損害補償業務マニュアル，1996

12. 首都高速道路補償センター, 工損調查標準仕様書（案）の解説，中央 用地対策連合協議会, 1992

13. 藤井衛 - 小宫一仁・伊奈潔・井上波彦・田村昌仁 : 建設工事に伴う住 宅被害の現状と健全性調査，土と基䃈Vol.47No.4，pp 15-18，1999.4

14. 田村昌仁，間片博文，藤井衛，伊奈潔：建設工事における周辺住宅の 地盤沈下被害の現状と対策講習会テキスト，地盤工学会，1997

15. 田村昌仁, 藤井衛, 河合直人, 植田静喜 : 戸建住宅を対象とした 基礎・地盤の性能評価の考え方, 土と基礎 Vol.49.No4, pp.4-7, 1980.6

16. 建設省建設経済局調整課監修，事業損失補償基準の解説，1991

17. 前田高冶 吉田 保 : 開削工事に伴う周辺地盤の挙動，土質工学会研 究発表会, pp158-159, 1985.6

18. 建築基磷構造設計指針 日本建築学会 2001.10

(2001年 9 月 21 日原稿受理, 2002 年 3 月 5 日採用決定 